UDC 339.548

\title{
TRANSFORMATION OF INTERNATIONAL TRADE IN THE CONTEXT OF TRADE CONFLICT BETWEEN THE UNITED STATES AND CHINA
}

\section{ТРАНСФОРМАЦІЯ МІЖНАРОДНОЇ ТОРГІВЛІ В КОНТЕКСТІ ТОРГОВЕЛЬНОГО КОНФЛІКТУ МІЖ США ТА КНР}

\author{
Dovgal Olena \\ V.N. Karazin Kharkiv National University \\ ORCID: https://orcid.org/0000-0003-3219-9731 \\ Dovgal Georgiy \\ V.N. Karazin Kharkiv National University \\ ORCID: https://orcid.org/0000-0002-0644-1793 \\ Miroshnichenko Tetyana \\ V.N. Karazin Kharkiv National University \\ ORCID: https://orcid.org/0000-0001-6114-4866
}

\author{
Довгаль Олена Андріївна \\ доктор економічних наук, професор, \\ Харківський національний університет імені В.Н. Каразіна \\ Довгаль Георгій Володимирович \\ кандидат економічних наук, доцент, \\ Харківський національний університет імені В.Н. Каразіна \\ Мірошниченко Тетяна Миколаївна \\ кандидат економічних наук, \\ Харківський національний університет імені В.Н. Каразіна
}

The article is devoted to current trends in the development of international trade, a gradual transition from the principles of openness, liberalization of international trade flows, to a policy of strengthening protectionism with longterm consequences for the global and national economies. The purpose of the article is to study the features and evolution of the trade conflict between the United States and China, as well as its consequences for the development of international trade. The economic and trade agreement between the United States and China marked the beginning of a period of truce in the trade confrontation between the two leading economic powers, but at the same time it became a new factor of uncertainty in the field of international trade. It is concluded that it is necessary to search for new forms and directions for the development of international economic relations both at the national, and at the regional and mega-regional levels.

Keywords: international trade, transformation, trade conflict, international economic relations, trade agreement.

Стаття присвячена актуальним тенденціям у розвитку міжнародної торгівлі, поступовим переходом від принципів відкритості, лібералізації міжнародних торговельних потоків, до політики посилення протекціонізму з довгостроковими наслідками для глобальної та національних економік. Метою статті є дослідження особливостей та еволюції торговельного конорлікту між США і Китаєм, а також його наслідків для розвитку міжнародної торгівлі. Доведено, що поряд із загальним підвищенням тарифів у міжнародній торгівлі 32018 року було відзначено збільшення використання нетарифних заходів різними країнами і групами країн. Проаналізовано загальну динаміку світового товарообміну і динаміку світового експорту та імпорту за групами країн останніми роками. При цьому найбільше зниження обсягу експортованої продукції в результаті торговельних суперечностей з США і підвищення напруженості в міжнародній торгівлі припадає на Китай. Досліджено наслідки американо-китайського торговельного конфлікту, які виходять за межі економічних відносин двох країн, враховуючи їх роль у світовій економіці і міжнародній торгівлі. Оскільки товарні потоки між США і Китаєм становлять найбільший обсяг взаємної торгівлі у всьому світі вплив американських тарифнних обмежень і відпо- 
відних заходів китайської сторони відчувається не тільки на ринках готової продукції, а й на проміжній стадії; через залученість національних виробників до глобальних виробничих ланцюжків вартості. Економічна і торговельна угода між США і Китаєм, названа першим етапом переговорного процесу, поклала початок періоду перемир'я у торговельному протистоянні двох провідних економічних держав, але ж при цьому стала новим чинником невизначеності у сфері міжнародної торгівлі. Нові напрямки регіональної політики США останніми роками впливають на всі боки взаємодії країн, i, в першу чергу, на торговельно-економічні зв'язки з країнами Індо-Тихоокеанського регіону. Робиться висновок про те, що в нових геополітичних й економічних умовах $€$ необхідним пошук нових форм і напрямків розвитку міжнародних економічних відносин з урахуванням сучасної ситуації, як на національному, так і на регіональному та мегарегіональном рівнях.

Ключові слова: міжнародна торгівля, трансформація, торговельний конфлікт, міжнародні економічні відносини, торговельна угода.

Статья посвящена актуальным тенденциям в развитии международной торговли, постепенным переходом от принципов открытости, либерализации международных торговых потоков, к политике усиления протекционизма с долгосрочными последствиями для глобальной и национальных экономик. Целью статьи является исследование особенностей и эволюции торгового конфллита между США и Китаем, а также его последствий для развития международной торговли. Экономическое и торговое соглашение между США и Китаем положило начало периоду перемирия в торговом противостоянии двух ведущих экономических держав, но при этом стало новым фрактором неопределенности в сорере международной торговли. Делается вывод, что необходим поиск новых форм и направлений развития международных экономических отношений как на национальном, так и на региональном и мегарегиональном уровнях.

Ключевые слова: международная торговля, трансформация, торговый конфрликт, международные экономические отношения, торговое соглашение.

Formulation of the problem. After more than half a century of advancing the policy of openness, liberalization of international trade flows in recent years will go down in history as a transition to strengthening protectionism with long-term consequences for global and national economies. The practice of economic attitudes, based primarily on national interests, does not disappear immediately, and its manifestations may later be present in various forms over a long period, spreading around the world.

Analysis of recent researches and publications. Numerous works of modern foreign and domestic economists are devoted to the study of current trends in the transformation of international trade. In foreign literature, this area of research is reflected in the works Allee T., Baldwin R., Bhagwati J., Lugg A., McColm J., Tucker T., Wall D. and other. In Ukrainian literature, these are the works of such authors as Lukyanenko D., Ostashko T., Serpukhov M., Tochilina T., Tsygankova T. and others. However, in our opinion, despite the large number of studies in this area, it is important to further analyze the transformation of international trade in the context of the trade conflict between the United States and China.

Thus, the purpose of the article is to study the features and evolution of the trade conflict between the United States and China, as well as its consequences for the development of international trade.

Presentation of the main research material. According to the World Trade Organization
(WTO), along with tariff increases in international trade in 2018, non-tariff measures increased by $16 \%$ [1], and in the Asia-Pacific region, each imported product accounted for an average of 2.5 non-tariff regulators, and $57 \%$ of merchandise imports were under at least one of these regulators [2]. The general dynamics of world trade in recent years has been volatile [3]. In 2018, the fastest growth rates of merchandise exports were observed in countries with economies in transition (22.7\%) - almost 2.5 times higher than imports. Commodity exports from African countries also increased at a faster pace than other groups of countries. In other groups of countries, the growth rates of merchandise exports and imports were close to the world average (Table 1 ).

In the group of developing countries in terms of merchandise exports, China was the leader ( $\$ 2,487 \mathrm{bln}$ ), exceeding by more than 8 times other major exporters of developing countries, including the Republic of Korea (\$605 bln), Mexico ( $\$ 451 \mathrm{bln}$ ) and Singapore ( $\$ 413 \mathrm{bln})$. China is also the largest importer of the developing world ( $\$ 2,136 \mathrm{bln})$, followed by the Republic of Korea (\$ 535 bln), India ( 514 bln), Mexico (\$ 477 bln) and Singapore ( $\$ 371 \mathrm{bln}$ ) [4]. In the group of developing and transition economies, the trade balance for goods remained positive, but for the former it decreased to $\$ 335$ bln in 2018 (from $\$ 455$ bln in 2014), and for the transition economies increased to $\$ 183$ bln (\$ 72 bln in 2016). At the same time, in the group of developed economies, the trade deficit by goods increased from $\$$ 
Table 1

Dynamics of merchandise exports and imports by groups of countries

\begin{tabular}{|l|c|c|c|}
\hline \multicolumn{1}{|c|}{ Countries } & $\begin{array}{c}\text { 2013, } \\
\text { bln dollars }\end{array}$ & $\begin{array}{c}\text { 2018, } \\
\text { bln dollars }\end{array}$ & $\begin{array}{c}\text { Annual growth } \\
\text { in 2018, \% }\end{array}$ \\
\hline \multicolumn{2}{|c|}{ Exports } & \multicolumn{3}{|c|}{} \\
\hline World & 18951 & 19453 & 9.7 \\
\hline Developing countries & 8436 & 8657 & 10.0 \\
\hline Including: in Africa & 591 & 484 & 14,7 \\
\hline in America & 1118 & 1086 & 9.2 \\
\hline in Asia and Oceania & 6727 & 7087 & 9.8 \\
\hline Countries with economies in transition & 806 & 674 & 22.7 \\
\hline Developed countries & 9708 & 10122 & 8.7 \\
\hline \multicolumn{1}{|c|}{ Imports } & \multicolumn{3}{|c|}{} \\
\hline World & 18966 & 19794 & 10.1 \\
\hline Developing countries & 8013 & 8322 & 11.0 \\
\hline Including: in Africa & 640 & 576 & 11.6 \\
\hline in America & 1168 & 1123 & 11.0 \\
\hline in Asia and Oceania & 6205 & 6623 & 9.4 \\
\hline Countries with economies in transition & 616 & 492 & 9.4 \\
\hline Developed countries & 10336 & 10980 & \\
\hline
\end{tabular}

634 bln in 2016 to $\$ 858$ bln in 2018. The dynamics of the world market for services in recent years shows its active development. World exports of services increased in 2018 by $7.7 \%$ - to 5.8 trillion dollars and amounted to $23.3 \%$ of the volume of world exports of goods and services [5]. At the same time, $67.9 \%$ of exports and $59.4 \%$ of imports of services in the world are accounted for by developed economies, while developing economies -29.7 and $37.8 \%$, respectively. In terms of growth in exports of services (12.4\%) in 2018, the leading economies were transitional economies, and in terms of growth in imports of services - the developing economies of Africa (11.9\%) (Table 2).

Of the developing countries in terms of exports and imports of services, China (4.57\%

Dynamics of export and import of services by groups of countries

\begin{tabular}{|c|c|c|c|}
\hline Countries & $\begin{array}{c}2013, \\
\text { bln dollars }\end{array}$ & $\begin{array}{c}2018, \\
\text { bln dollars }\end{array}$ & $\begin{array}{l}\text { Annual growth } \\
\text { in 2018, \% }\end{array}$ \\
\hline \multicolumn{4}{|l|}{ Exports } \\
\hline World & 4841 & 5845 & 7.7 \\
\hline Developing countries & 1394 & 1738 & 9.3 \\
\hline Including: in Africa & 99 & 118 & 9.4 \\
\hline in America & 170 & 190 & 1.7 \\
\hline in Asia and Oceania & 1125 & 1430 & 10.4 \\
\hline Countries with economies in transition & 137 & 137 & 12.4 \\
\hline Developed countries & 3310 & 3970 & 6.8 \\
\hline \multicolumn{4}{|l|}{ Imports } \\
\hline World & 4726 & 5604 & 7.4 \\
\hline Developing countries & 1745 & 2118 & 8.1 \\
\hline Including: in Africa & 177 & 178 & 11.9 \\
\hline in America & 236 & 222 & 0,9 \\
\hline in Asia and Oceania & 1,333 & 1,718 & 8.7 \\
\hline Countries with economies in transition & 194 & 158 & 7.8 \\
\hline Developed countries & 2787 & 33277.0 & 7.0 \\
\hline
\end{tabular}


of world exports and $9.37 \%$ of imports), India (3.51\% of exports and $3.15 \%$ of imports), Singapore (3.15\% of exports and 3.34\% of imports). Of the countries with economies in transition, Serbia (16.4\% in 2018), Russia (12.3\%), and Kazakhstan (11.8\%) stand out in terms of the growth rate of exports of services. The main exporter and importer of services is the United States. The volume of their exports significantly exceeds the volume of exports of services of other countries, accounting for $14 \%$ of the world, and imports of services $-9.98 \%$ of the world. Of the other developed economies, the United States is followed by Great Britain, Germany, France, and the Netherlands in terms of exports of services, and Germany, France, Great Britain, and the Netherlands in terms of imports of services. Trade in telecommunications, computer and information services is growing at the fastest pace (in 2018 - by 14.7\%), almost doubling the growth rate of transport, tourism, financial and other services. At the same time, the largest decrease in the volume of exported products as a result of trade disputes with the United States and increasing tensions in international trade falls on China. Imports of Chinese products to the United States in the first half of 2019 ( $\$ 235.1$ bln) decreased by $\$ 32.7$ bln compared to the first half of 2018, when it amounted to $\$ 267.8 \mathrm{bln}$. US merchandise exports to China fell by $\$ 12.4$ bln over the same period (from $\$ 67.4$ bln to $\$ 55.1 \mathrm{bln}$ ) [6].

The consequences of the US-China trade conflict go beyond the economic relations of the two countries, given their role in the world economy and international trade. Trade flows between the United States and China account for the largest volume of mutual trade in the world with annual Chinese exports to the United States worth \$ 540 bln in 2020 and imports to China of American products worth about $\$ 121$ bln [7]. The influence of American tariff restrictions and Chinese responses is felt not only in the finished products markets, but also in the intermediate stage; due to the involvement of national producers in global production chains. Tariff changes are one of the key factors influencing international trade flows, but not the only one. When the United States singled out countries that asymmetrically benefited from bilateral trade, it was also about the possibility of these countries, and especially China, using currency manipulation [8]. Speaking at the World Economic Forum in Davos in January 2020, Trump stressed the importance of signing an economic and trade agreement between the US and Chinese governments, as well as concluding a trade agreement with Canada and Mexico (USMCA), calling them a new trade model for current model (new model of trade for the 21st century) [9]. Prior to that, in 2019, the United States also concluded a new trade agreement with Japan.

The Economic and Trade Agreement between the United States and China, called the first stage of the negotiation process, marked the beginning of a period of truce in the trade confrontation between the two leading economic powers, and became a new factor of uncertainty in international trade. When China's announced purchases of American products reach in two years, supplies to China from the EU, as well as from Brazil, Argentina, Australia, New Zealand, South Korea, Japan and a number of other countries, are in question. According to some estimates, the biggest losses threaten the EU [10]. Many leading researchers in international economic relations, including the United States, have already expressed doubts about the feasibility of implementing this agreement. At the same time, the prospects for the abolition of tariffs introduced in recent years remain unclear [11]. International experts are wondering whether this Agreement will become a "new normality". After all, according to this Agreement, part of the introduced tariffs is reduced, but a significant part of US tariffs on products worth hundreds of billions of dollars remains, while the increase in supplies of American products to China is provided relative to the volume of 2017 before tariff increases [12].

After a period of tariff and other restrictions, on the eve of the upcoming presidential election (in November 2020), the US administration proceeded to conclude new trade agreements. The first phase of the Economic and Trade Agreement between the United States Government and the Government of China marked the beginning of the US trade truce with one of its key trading partners and a major source of the US trade deficit. In addition to the provisions directly regulating trade in goods, the Agreement covers a wide range of issues related to intellectual property rights, development of trade in services, technological exchange, and also contains the following sections: 1) intellectual property; 2) technology transfer; 3) trade in food and agricultural products; 4) financial services; 5) macroeconomic policies and exchange rate matters and transparency; 6) expanding trade; 7) bilateral evaluation and dispute resolution; 8) final provisions.

The increase in exports from the United States to China is recorded in Section 6 of the Expand- 
ing Trade Agreement. This section states that in the period from January 1, 2020 to December 31, 2021, the Chinese side will increase imports from the United States of manufacturing, agricultural products, energy, services by at least $\$ 200$ bln relative to the volume of 2017 [13]. A detailed list of promises from China covers a wide range of diverse products. The starting point for the increase in exports to China from the United States is the volume of US exports to China in 2017 ( $\$ 186.3 \mathrm{bln}$, when it was $\$ 8.5 \mathrm{bln}$ higher than in 2018 (\$ $177.8 \mathrm{bln})$, and commodity exports from the United States to China in 2017 (\$130.3 bln) exceeded the volume of 2018 (\$ 120.8 bln) by $\$ 9.5$ bln [14]. The very question of making such large-scale purchases of American products adds new elements to trade relations between countries, limiting the factor of competition. In fact, we are talking about sales guarantees for American exporters. Increasing imports of American products to such an extent could be a serious challenge for suppliers to the Chinese market from other countries. The US-led increase in exports from the United States to China is a new element of trade cooperation with the goal of expanding US exports and reducing the US trade deficit with China. As for customs tariffs, according to the Agreement, the United States will reduce them from 15 to $7.5 \%$ on imports of Chinese products worth about $\$ 100 \mathrm{bln}$; but the $\$ 25$ bln in product tariffs introduced remain unchanged. The agreement provides for further consultations, negotiations, as well as the return of the American side to higher duties in case of breach of obligations by the Chinese side.

Concluding new types of agreements, the trade practices of the United States not only change the nature of their relations with other countries, but also become a factor influencing the entire system of international economic relations. Areas of US-China confrontation go beyond direct trade relations, covering the scientific and technological sphere, issues of protection of intellectual property rights. At the end of 2019, it was not just about economic disagreements. Following congressional approval, the President of the United States signed the Hong Kong Human Rights and Democracy Act of 2019, which deals with the domestic political situation in Hong Kong. Under the law, sanctions may be imposed on people suspected of human rights abuses in Hong Kong. At the same time, restrictions were imposed on the use of American police equipment to disperse protesters, banning the export of such equipment from the United States to the police in Hong Kong. Such decisions can ultimately only exacerbate US-China economic differences, turning them into political ones and making further trade talks between the two countries more difficult.

New directions of US regional policy in recent years have affected all aspects of cooperation between countries, including trade and economic ties. In the 2017 National Security Strategy, the Indo-Pacific region is ranked first in the "Strategy in a Regional Context" section. The proclaimed Free and Open Indo-Pacific region emphasizes the special role of strategic relations with countries that share concerns about China's growing influence. Such countries include Japan, Australia and India [15].

In September 2019, a quadripartite consultation was held on further cooperation in the region. At the same time, the presidential initiative of the Indo-Pacific Strategy was supported by the United States Congress. Giving priority to the new format of relations in the Asia-Pacific region, White House documents emphasize the importance of fair trade for the United States. For these purposes, preference is given to countries that share the American position. In essence, the Indo-Pacific strategy of the current United States administration in the field of economic relations is a continuation of the revision of a number of trade agreements, withdrawal from the Trans-Pacific Partnership, identification of key trade rivals, especially China, harming the US economy.

Conclusions. Thus, the new US strategy for Asia and the Pacific in the context of China's deterrence may also become a factor in changing international trade relations in the coming years. Against the background of tensions between the world's leading trade centers, especially between the United States and China, new perspectives are emerging, which were discussed, including at the New Economy Forum in Beijing on November 21-22, 2019, which stressed that "new markets and new leaders have an unprecedented impact on global economic change", "new opportunities are emerging" [16]. Given the uncertainty in the development of international trade relations, largely determined by the leading players in world markets, other countries are considering new areas and forms of cooperation. In the new geopolitical and economic conditions it is necessary to find new forms and directions of international economic relations taking into account the current situation, both at the national and regional, megaregional levels. 


\section{REFERENCES:}

1. Statistics. Trade and tariff data. WTO. Available at: https://www.wto.org/english/res_e/statis_e/statis_e.htm

2. Asia-Pacific Trade and Investment Report 2019. Available at: https://unctad.org/en/PublicationsLibrary/ APTIR2019_ExecutiveSummary_en.pdf

3. Key Statistics and Trends in International Trade. UNCTAD. 2019. URL: https://unctad.org/en/Publications Library/ditctab2019d2_en.pdf

4. UNCTAD Handbook of statistics. 2019. Available at: https://unctad.org/webflyer/handbook-statistics-2019

5. International Trade in Services. UNCTAD, 2019, May 28. Available at: https://unctad.org/system/files/ official-document/gdsdsimisc2019d9_en.pdf

6. U.S. International Data International Transactions, International Services, and International Investment Position Tables. BEA, 2019, October. Available at: https://apps.bea.gov/iTable/iTable.cfm?reqid=62\&step=1\&isuri=1\#reqid\%20 $=62 \&$ step $=1 \&$ isuri $=1$

7. U.S. International Trade. Survey of Current Business. 2020, January. Available at: https://apps.bea.gov/scb/ 2020/01

8. Trade and Development Report. UNCTAD, 2019. Available at: https://unctad.org/en/PublicationsLibrary/ tdr2019_en.pdf

9. Remarks by President Trump at the World Economic Forum. Davos, Switzerland. White House, 2020, January 21. Available at: https://www.whitehouse.gov/briefings-statements/remarks-president-trump-world-economicforum-davos-switzerland/

10. The EU is The Biggest Loser from US-China Agreement. Available at: https://zerohedge.whotrades.com/ blog/43445683905

11. National Security Strategy of the United States of America. Washington. The White House, 2017, December. Available at: https://www.whitehouse.gov/wp-content/2017/12/

12. Bown Ch. P. Phase One China Deal: Steep Tariffs Are the New Normal. PIIE, 2019, December 19. Available at: https://www.piie.com/blogs/trade-and-investment-policy-watch/phase-one-china-deal-steep-tariffs-are-new-normal

13. Economic and Trade Agreement between the Government of the United States of America and the Government of the People's Republic of China. Phase one, 2020, January 15. Available at: https://ustr.gov/countriesregions/china-mongolia-taiwan/peoples-republic-china/phase-one-trade-agreement/text

14.US International Trade. Survey of Current Business, 2020, January. Available at: https://apps.bea.gov/ scb/2020/01-january/pdf/0120-international-transactions-tables.pdf

15. Despite the US-China Trade Agreement, Key Details are Unclear. CNBC. Available at: https://www.cnbc.com/ 2019/12/16/us-and-china-reached-a-trade-agreement-but-key-details-still-unclear.html

16. New Economy Forum, Beijing, November 20-22, 2019. Bloomberg New Economy Forum. Available at: https://www.neweconomyforum.com/2019-new-economy-forum-beijing/

\section{СПИСОК ВИКОРИСТАНИХ ДЖЕРЕЛ:}

1. Statistics. Trade and tariff data. WTO. URL: https://www.wto.org/english/res_e/statis_e/statis_e.htm

2. Asia-Pacific Trade and Investment Report 2019. URL: https://unctad.org/en/PublicationsLibrary/APTIR2019_ ExecutiveSummary_en.pdf

3. Key Statistics and Trends in International Trade. UNCTAD. 2019. URL: https://unctad.org/en/PublicationsLibrary/ditctab2019d2_en.pdf

4. UNCTAD Handbook of statistics. 2019. URL: https://unctad.org/webflyer/handbook-statistics-2019

5. International Trade in Services. UNCTAD, 2019, May 28. URL: https://unctad.org/system/files/official-document/gdsdsimisc2019d9_en.pdf

6. U.S. International Data International Transactions, International Services, and International Investment Position Tables. BEA, 2019, October. URL: https://apps.bea.gov/iTable/iTable.cfm?reqid=62\&step=1\&isuri=1\#reqid\%20= $62 \&$ step $=1 \&$ isuri $=1$

7. U.S. International Trade. Survey of Current Business. 2020, January. URL: https://apps.bea.gov/scb/2020/01

8. Trade and Development Report. UNCTAD, 2019. URL: https://unctad.org/en/PublicationsLibrary/tdr2019_en.pdf

9. Remarks by President Trump at the World Economic Forum. Davos, Switzerland. White House, 2020, January 21. URL: https://www.whitehouse.gov/briefings-statements/remarks-president-trump-world-economic-forum-davos-switzerland/

10. The EU is The Biggest Loser from US-China Agreement. URL: https://zerohedge.whotrades.com/blog/ 43445683905

11. National Security Strategy of the United States of America. Washington. The White House, 2017, December. URL: https://www.whitehouse.gov/wp-content/2017/12/ 
12. Bown Ch. P. Phase One China Deal: Steep Tariffs Are the New Normal. PIIE, 2019, December 19. URL: https://www.piie.com/blogs/trade-and-investment-policy-watch/phase-one-china-deal-steep-tariffs-are-new-normal

13. Economic and Trade Agreement between the Government of the United States of America and the Government of the People's Republic of China. Phase one, 2020, January 15. URL: https://ustr.gov/countries-regions/ china-mongolia-taiwan/peoples-republic-china/phase-one-trade-agreement/text

14.US International Trade. Survey of Current Business, 2020, January. URL: https://apps.bea.gov/scb/ 2020/01-january/pdf/0120-international-transactions-tables.pdf

15. Despite the US-China Trade Agreement, Key Details are Unclear. CNBC. URL: https://www.cnbc.com/ 2019/12/16/us-and-china-reached-a-trade-agreement-but-key-details-still-unclear.html

16. New Economy Forum, Beijing, November 20-22, 2019. Bloomberg New Economy Forum. URL: https://www.neweconomyforum.com/2019-new-economy-forum-beijing/ 